\title{
CABARAN KALENDAR ISLAM GLOBAL DI ERA REVOLUSI INDUSTRI 4.0
}

\section{Global Islamic Calendar Challenge in Era Industrial Revolution 4.0}

\author{
Susiknan Azhari*
}

\begin{abstract}
Muslims' aspiration to have an international or global Islamic calendar has long been discoursed through various meetings nationally and internationally. In this context, Malaysia has played an imperative role through the "World Conference on International Islamic Calendar" on 29 Rabiul Awal-2 Rabiul Akhir 1412 H/8-10 October 1991 at Science University of Malaysia (USM) Penang. This meeting instigated programs and steps towards the unification of the International Islamic Calendar and also known as the "Penang Declaration of 1991. In 2016/1437, Conference on the Unification of the Islamic Calendar which had been held in Turkey has established the concept of global Islamic calendar. The Principle of the Global Islamic Calendar has an epistemological basis that allows the realization of "One Day One Date for the Whole World". However, not entire Muslim recognized the Turkey's 2016/1437 results positively. The tendency of rejection is more influenced by the fiqh aspect. Some Muslim assume
\end{abstract}

Professor, UIN Sunan Kalijaga, Yogyakarta, Indonesia. susiknanazhari69@gmail.com 
that the Turkey's 2016/1437 decision ignores the "fiqh" the concept of matla' so which has been applied all this while. Therefore, tahawwul al-fikr of Islamic calender from locality to global base is vital by reviving the understanding of hadìths regarding ru'yah and matla'.

Keywords: Hijri, IR.4.0, Global, Islamic Calendar

\section{PENDAHULUAN}

Perkataan "revolusi" menunjukkan perubahan yang radikal dan mendadak. Sepanjang sejarah manusia, revolusi terjadi ketika teknologi-teknologi mutakhir dan cara-cara baru dalam melihat dunia memacu perubahan mendalam pada sistem kehidupan manusia. Revolusi Industri 4.0 merupakan istilah yang tidak asing bagi masyarakat dunia kini. ${ }^{1}$ Perkembangan teknologi dan informasi semakin pantas dalam kalangan masyarakat. Kesannya sangat besar bagi dunia industri mahupun perilaku dalam kalangan masyarakat. Pada ketika ini, akses informasi sangat mudah dan dapat dilakukan pada bila-bila masa dan di mana sahaja melalui jaringan internet.

Perkembangan teknologi tersebut turut memberikan kesan positif dalam bidang astronomi Islam, khususnya dalam hal penentuan awal bulan kamariah. Sebagai contoh, cerapan awal bulan kamariah kini dapat dijalankan melalui live streaming antara negara sebagaimana dilakukan oleh APADILANGIT kerjasama dengan Jabatan Kemajuan Islam Malaysia (JAKIM) dan Universiti Malaya mengadakan cerapan bersama antara Indonesia dan Malaysia. ${ }^{2}$

\footnotetext{
Di Jerman, wacana mengenai “Industri 4.0” telah dibicarakan semasa penganjuran Hannover Fair 2011. Selengkapnya lihat Klaus Schwab. Revolusi Industri Keempat, cet. 1, (Jakarta: Gramedia, 2020), 3.

2 Kegiatan ini berlangsung ketika observasi awal bulan Zulhijah 1441 $\mathrm{H}$ dijalankan dengan melibatkan pelbagai pos observasi di Indonesia dan Malaysia, seperti Observatorium Bosscha, Balai Cerap Teluk Kemang Negeri Sembilan, Balai Cerap UnisZa Terengganu, Balai Cerap Al-Biruni Sabah, dan Rukyatul Hilal Indonesia Yogyakarta.
} 
Peristiwa tersebut belum pernah terjadi sebelumnya dan merupakan peristiwa pertama dan perlu dilanjutkan tidak hanya kawasan anggota MABIMS (Pertemuan Tahunan Tidak Rasmi Menteri-Menteri Agama; Negara Brunei Darussalam, Republik Indonesia, Malaysia dan Republik Singapura). Hal ini menjadi cabaran sekali gus memberi peluang kepada para pencinta bidang astronomi Islam agar giat mengadakan wacana semasa berkaitan Kalendar Islam di peringkat global. Tulisan ini akan melihat perkembangan sistem Kalendar Islam dan strategi mewujudkan Kalendar Islam global di Era Revolusi Industri 4.0.

\section{KALENDAR ISLAM YANG BERKEMBANG DI KAWASAN ANGGOTA MABIMS}

Kawasan anggota MABIMS berkembang pelbagai sistem Kalendar Islam. Indonesia sebagai negara yang majoriti berpenduduk muslim, memiliki beragam Kalendar Islam yang berkembang dalam kalangan masyarakat. Keragaman ini merupakan keunikan sekali gus cabaran bagi usaha penyatuan kalendar Islam di Indonesia. Terdapat empat kalendar, iaitu kalendar Muhammadiyah, Almanak PB NU, Taqwim Standar Indonesia Kementerian Agama RI, dan Almanak Islam PERSIS. ${ }^{3}$ Masing-masing memiliki sistem dan kriteria yang berbeza dalam penentuan awal bulan Hijri, khususnya Ramadan, Syawal, dan Zulhijah. Kalendar Muhammadiyah menggunakan hisab hakiki wujūd al-hiläl secara konsisten sejak Muharam hingga Zulhijah. Almanak PB NU menggunakan visibilitas hilal MABIMS, sedangkan untuk Ramadan dan Syawal menunggu hasil rukyah al-hilāl.

Namun, kini hasil rukyah al-hilāl digunakan semua bulan kamariah sejak Muharam hingga Zulhijah. Polisi ini pernah beberapa kali menimbulkan perbezaan antara data hisab pada Almanak dengan hasil rukyah al-hilāl di lapangan, seperti dalam hal penetapan awal Muharam $1438 \mathrm{H}$. Almanak PB NU menetapkan awal Muharam 1438H adalah pada 2 Oktober 2016 (Ahad), namun pada 1 Oktober 2016 (Sabtu) tiada laporan keberhasilan melihat

Huraian selengkapnya lihat Susiknan Azhari, "Gagasan Menyatukan Umat Islam Indonesia,” Jurnal Ahkam 15, no. 2 (2015), 249-258. 
hilal, maka Lembaga Falakiyah PB NU mengeluarkan kenyataan bahawa awal Muharam $1438 \mathrm{H}$ adalah pada 3 Oktober 2016 (Isnin). Kenyataan ini menimbulkan kekeliruan bagi pengikut Nahdlatul Ulama dan menimbulkan perbezaan dengan Muhammadiyah dan Pemerintah dalam memulakan tahun baru $1438 \mathrm{H}$. Hal yang sama juga terjadi dalam penentuan awal Jamadil Awal $1439 \mathrm{H}$.

Sementara itu, PERSIS dalam menentukan awal bulan kamariah hampir sama dengan sistem yang dikembangkan Muhammadiyah. Perbezaan terletak pada urutan penggunaannya. Perjalanan Muhammadiyah dalam menggunakan kriteria untuk menentukan awal bulan kamariah, iaitu (1) imkān al-rukyah, (2) ijtimā' qabl al-ghurūb, dan (3) wujūd al-hilāl, sedangkan kriteria yang digunakan PERSIS adalah (1) ijtima $\bar{a}^{\prime}$ qabl al-ghurūb, (2) wujūd al-hilāl, dan (3) imkān al-rukyah, dan (4) Imkanur Rukyat LAPAN dengan syarat (1) beza tinggi antara bulan dan matahari minimum 4 darjah dan (2) jarak sudut (elongasi) antara bulan dan matahari minimum 6.4 darjah. Teori ini diadaptasi dari "Kriteria Hisab Rukyat Indonesia" yang dikembangkan oleh T. Djamaluddin. ${ }^{4}$

Di Malaysia, Mohd Saiful Anwar Mohd Nawawi menjelaskan bahawa sistem kalendar Islam yang digunakan mengalami perkembangan sesuai tuntutan zaman dan terbahagi kepada empat peringkat. ${ }^{5}$ Peringkat pertama (sebelum 1969-1986) menggunakan kalendar Istilahi. Kalendar ini berdasarkan hisab urfi namun dalam penentuan awal Ramadan dan Syawal menunggu hasil observasi dari masing-masing negeri atau mengikuti negeri lain. Pada peringkat ini, kalendar Islam disusun oleh para ahli falak masing-masing negeri dan teori yang digunakan berbeza sehingga sering menimbulkan perbezaan.

4 Huraian selengkapnya lihat Thomas Djamaluddin, Astronomi Memberi Solusi Penyatuan Ummat (Jakarta: LAPAN, 2011), 23.

5 Penjelasan selengkapnya lihat Mohd Saiful Anwar Mohd Nawawi, "Penilaian Semula Kriteria Kenampakan Anak Bulan di Malaysia, Indonesia dan Brunei," (Tesis Doktor Falsafah, Jabatan Fiqh dan Usul, Akademi Pengajian Islam, Universiti Malaya, Kuala Lumpur, 2013), 110. Lihat juga Mohd Saiful Anwar Mohd Nawawi et al., "History of the Criteria for Lunar Crescent Visibility in Malaysia", Jurnal Al-Tamaddun, Bil 10 (2) 2015, 63. 
Peringkat kedua (1986-1991) menggunakan Kalendar Ijtimak Hakiki. Sekiranya peristiwa ijtimak berlaku sebelum terbenam matahari, maka tanggal baharu bermula apabila terbenam matahari. Namun, sekiranya ijtimak terjadi sesudah matahari terbenam, maka ketika terbenam matahari belum dianggap tanggal baru ataupun bulan yang sedang berjalan dilanjutkan kepada 30 hari. Teori ini digunakan untuk menentukan semua awal bulan kamariah kecuali Ramadan dan Syawal menggunakan visibilitas hilal hasil Persidangan Istanbul Turki 1978 yang telah disesuaikan dengan keadaan Malaysia sebagaimana sebelumnya. Ini bermaksud syarat-syarat yang ditentukan digunakan secara alternatif bukan kumulatif. Hal ini dapat diperhatikan dalam menentukan awal Ramadan 1407 H. Untuk lebih jelasnya perhatikan jadual berikut.

Jadual 1: Perbandingan Kedudukan Hilal di Teluk Kemang Ketika Terbenam Matahari Dengan Visibilitas Hilal Turki 1978

\begin{tabular}{|l|c|c|}
\hline & 28.04 .87 & Syarat Visibilitas Hilal \\
\hline Ketinggian Hilal & $+02^{\circ} 19^{\prime}$ & $+5^{\circ} 30^{\prime}$ \\
\hline Elongasi & $4^{\circ} 34^{\prime}$ & $7^{\circ} 30^{\prime}$ \\
\hline Umur Bulan & $09 \mathrm{j} 42 \mathrm{~m}$ & $8 \mathrm{jam}$ \\
\hline $\begin{array}{l}\text { Sudah atau belum } \\
\text { lahir hilal awal } \\
\text { Ramadan }\end{array}$ & Sudah & \\
\hline
\end{tabular}

Sumber: Abdul Hamid Tahir (1990)

Jadual di atas menunjukkan dari tiga syarat yang ditentukan hanya satu syarat yang dipenuhi, iaitu umur bulan (9 j $42 \mathrm{~m})$. Berpandukan visibilitas hilal di Malaysia yang bersifat alternatif, maka kondisi seperti ini dianggap sudah memenuhi visibilitas hilal dan awal Ramadan 1407 adalah pada 29 April 1987 (Rabu) meskipun tidak dapat melihat hilal pada 28 April 1987.

Peringkat ketiga (1992-1994) menggunakan kalendar ijtimak wujūd al-hilāl. Sekiranya telah berlaku ijtimak sebelum matahari terbenam dan kedudukan hilal di atas ufuk setelah Matahari terbenam, maka pada ketika itu dianggap bermula tanggal baharu. Teori ini digunakan untuk semua bulan kamariah kecuali Ramadan dan Syawal masih menggunakan teori visibilitas hilal yang digunakan sebelumnya. Penggunaan sistem kalendar ini hanya berlangsung selama dua tahun. 
Peringkat keempat berlangsung sejak dari tahun 1995 hingga kini menggunakan kalendar Imkanur Rukyat atau "Takwim Rukyat". ${ }^{6}$ Secara amalan, imkanur rukyat yang digunakan adalah imkanur rukyat MABIMS. Awal bulan kamariah bermula apabila matahari terbenam memenuhi syarat berikut.

a) Altitude atau ketinggian hilal tidak kurang dari 2 darjah DAN

b) Jarak lengkung (elongasi) Matahari ke Bulan tidak kurang dari 3 darjah ATAU

c) Ketika Bulan terbenam umur Bulan tidak kurang dari 8 jam. ${ }^{7}$

Syarat-syarat di atas bersifat alternatif. Jika ketinggian dan elongasi sudah memenuhi, maka keesokan harinya dianggap sudah memasuki awal bulan kamariah. Sekiranya ketinggian dan elongasi belum memenuhi (manakala umur bulan sahaja sudah memenuhi), maka keesokan harinya juga sudah dianggap memasuki awal bulan kamariah. Metode ini digunakan untuk semua awal bulan kamariah termasuk Ramadan, Syawal, dan Zulhijah. Dalam proses perhitungan terdapat dua lokasi (markaz) yang dijadikan rujukan, iaitu Tanjung Atiam Sabah dan Tanjung Chinchin Langkawi. Keduanya digunakan sesuai dengan kedudukan geografi untuk mewakili seluruh wilayah di Malaysia. Tanjung Chincin berada pada lokasi paling Barat dan Tanjung Atiam Sabah berada pada lokasi paling Timur.

6 Istilah "Takwim Rukyat" digunakan oleh Mohd Khair. Lihat Haji Md Khair Haji Md Taib, Takwim Hijriah Khairiah (Bangi: Penerbit Universiti Kebangsaan Malaysia, 1987), 28.

7 Selengkapnya lihat Ahmad Yusof Farid Abdullah. Kaedah Penetapan Awal Ramadhan \& Syawal dan Pembentukan Taqwim Hijri di Malaysia, cet. 1 (Pulau Pinang: Jabatan Mufti Pulau Pinang, t.t.), 8. 
Cabaran Kalendar Islam Global di Era Revolusi Industri 4.0

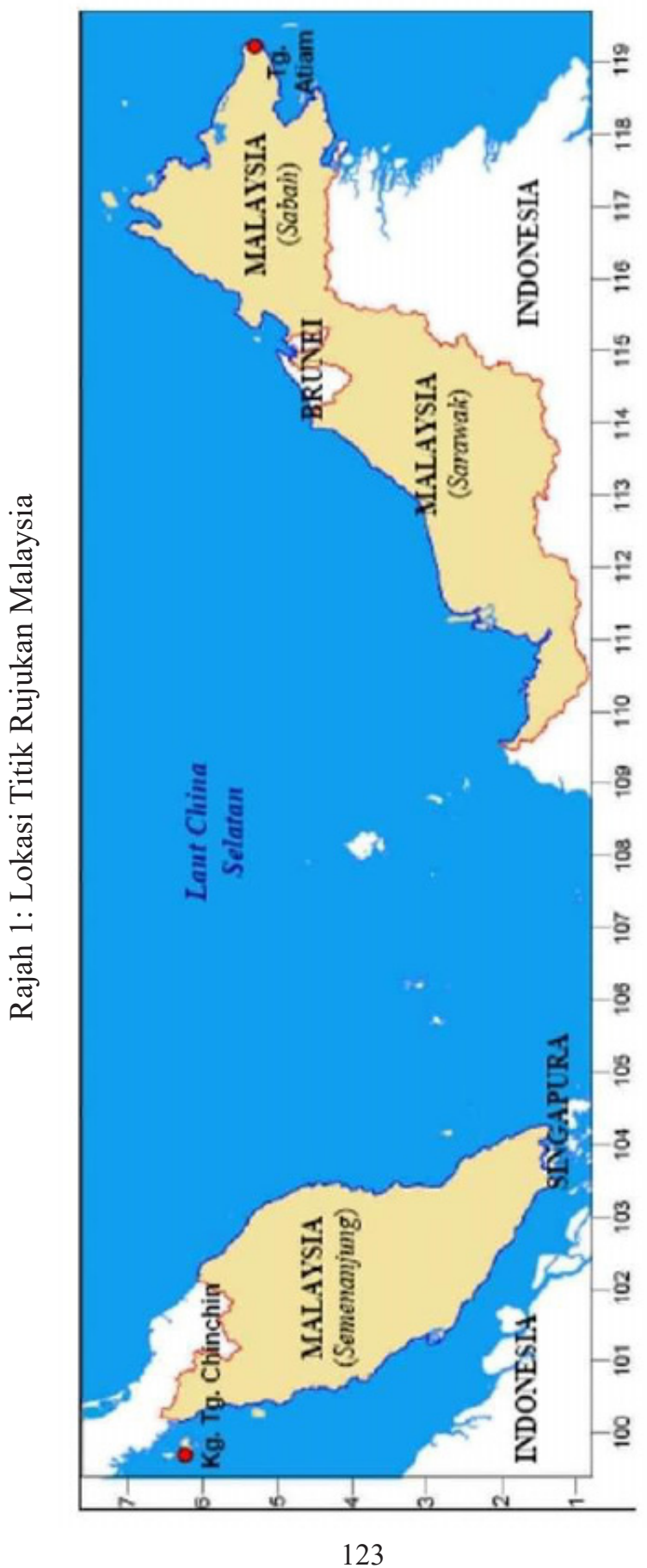


Dengan demikian, diharapkan seluruh wilayah di Malaysia sudah diwakili. Selanjutnya sebagai panduan penentuan awal bulan kamariah data yang diambil bersumber dari salah satu markaz. Sekiranya salah satu markaz sudah memenuhi salah satu syarat visibilitas hilal MABIMS, maka keesokan harinya ditetapkan awal bulan kamariah. Sebagai contoh penentuan awal Syawal $1432 \mathrm{H}$ adalah sepertimana berikut:

Jadual 2: Data Kedudukan Hilal 29 Ramadan 1432/29 Ogos 2011

\begin{tabular}{|l|c|c|c|c|c|}
\hline \multicolumn{1}{|c|}{ Lokasi } & $\begin{array}{c}\text { Matahari } \\
\text { Terbenam }\end{array}$ & $\begin{array}{c}\text { Ketinggian } \\
\text { Hilal }\end{array}$ & Elongasi & $\begin{array}{c}\text { Umur } \\
\text { Bulan }\end{array}$ & Kesimpulan \\
\hline Tanjung Chinchin & 18.11 & $00^{\circ} 07^{\prime}$ & $06^{\circ} 16^{\prime}$ & $7 \mathrm{j} 09 \mathrm{~m}$ & Belum \\
\hline Tanjung Atiam & 19.30 & $00^{\circ} 35^{\prime}$ & $06^{\circ} 42^{\prime}$ & $8 \mathrm{j} 30 \mathrm{~m}$ & Sudah \\
\hline $\begin{array}{l}\text { Syarat Visibiltas } \\
\text { Hilal MABIMS }\end{array}$ & & $02^{\circ} 00^{\prime}$ & $03^{\circ} 00^{\prime}$ & $8 \mathrm{j} 00 \mathrm{~m}$ & \\
\hline
\end{tabular}

Sumber: Mohd Saiful Anwar (2013)

Jadual di atas menjelaskan bahawa ketinggian hilal dan elongasi dari dua lokasi belum memenuhi syarat visibilitas hilal MABIMS, begitu juga umur bulan di Tanjung Chinchin. Namun umur bulan di Tanjung Atiam sudah memenuhi syarat visibilitas hilal MABIMS, iaitu 8 jam 30 minit. Oleh yang demikian, awal Syawal 1432H ditetapkan adalah pada 30 Ogos 2011. Hal ini menunjukkan pada peringkat ini, sistem kalendar yang digunakan di Malaysia sudah mapan dan konsisten disebabkan semua awal bulan kamariah menggunakan teori yang sama, iaitu visibilitas hilal MABIMS tanpa menunggu hasil cerapan hilal. ${ }^{8}$ Oleh yang demikian, Mohammad Odeh ketika mempresentasikan kalendar Islam yang berkembang di Dunia Islam pada konferensi di Istanbul

8 Menurut Azhari Muhammad, sebelumnya teori imkanur rukyat hanya digunakan untuk menentukan awal Ramadan, Syawal, dan Zulhijah. Bulan-bulan yang lain menggunakan wujūd al-hilāl. Namun sejak tahun 1995, Jawatan Kuasa Teknikal Kalendar Islam menetapkan penggunaan imkanur rukyat untuk semua bulan dan takwim hijri Malaysia. Lihat Azhari Muhammad, "Pembentukan Takwim Islam Malaysia Tahun 2000," (Kertas kerja, Muzakarah Pegawai-pegawai Falak Seluruh Malaysia di Hotel Seri Malaysia Kuala Terengganu, 8-12 September 1999). 
Turki tahun 1436/2013 memasukkan Malaysia sebagai salah satu negara yang memiliki kalendar Islam yang mapan. ${ }^{9}$

Langkah Malaysia ini juga diikuti Singapura. Kalendar Islam Singapura yang dikeluarkan oleh Majelis Ugama Islam Singapura (MUIS) didasarkan pada kriteria visibilitas hilal MABIMS yang digunakan untuk bulan Muharam hingga Zulhijjah tanpa menunggu hasil rukyah al-hilāl. Brunei Darussalam turut menggunakan kriteria visibilitas hilal MABIMS dalam pembuatan kalendar Islam. Hanya dalam menentukan awal Ramadan, Syawal, dan Zulhijah sahaja menunggu hasil rukyah al-hilāl. Sikap ini sama dengan Indonesia. Dengan kata lain, pengguna kriteria visibilitas hilal MABIMS belum semua anggota melaksanakan secara konsisten.

Akibatnya sesama anggota MABIMS terjadi perbezaan dalam penentuan awal dan akhir Ramadan. Hal ini dapat diperhatikan dalam penentuan awal dan akhir Ramadan $1440 \mathrm{H} .{ }^{10}$ Indonesia, Malaysia, dan Singapura menetapkan awal Ramadan $1440 \mathrm{H}$ adalah pada 6 Mei 2019 (Rabu). Sedangkan Brunei Darussalam menetapkan awal Ramadan 1440M adalah pada 7 Mei 2019 (Khamis). Keadaan ini turut menyebabkan perbezaan dalam

$9 \quad$ Menurut Mohammad Odeh hanya ada dua negara yang memiliki kalendar Islam yang mapan, iaitu Turki dan Malaysia. Huraian selengkapnya lihat Muhammad Shawkah 'Awdah, "al-Ma'āyir alFalākiyyah li bad'i al-Ashhūr al-Hijriyyah fĩ al-'Alam al-Islāmī wa Waqi' al-Ummah fì al-Waqt al-Rahin," (Kertas kerja, The Preparation Meeting for International Crescent Observation Conference, Istanbul Turki, 18-19 Februari 2013), 2. Lihat juga Susiknan Azhari, Catatan \& Koleksi Astronomi Islam dan Seni, cet. I, (Yogyakarta: Museum Astronomi Islam, 2015), 9.

10 Selengkapnya lihat www.icoproject.org. diakses pada 20 Julai 2019. 
mengakhiri Ramadan 1440H. ${ }^{11}$ Indonesia, Malaysia, dan Singapura menetapkan awal Syawal 1440 adalah pada 5 Jun 2019 (Rabu), sedangkan Brunei Darussalam menetapkan awal Syawal 1440H adalah pada 6 Jun 2019 (Khamis). Selanjutnya pada permulaan bulan Zulkaedah 1440H Brunei Darussalam mengikuti Takwim MABIMS sehingga menyebabkan umur bulan Syawal 1440 di Brunei Darussalam hanya 28 hari. $^{12}$

\section{KALENDAR ISLAM LOKAL DAN SERANTAU MENUJU KALENDAR ISLAM GLOBAL}

Keinginan umat Islam memiliki kalendar Islam global telah lama diwacanakan melalui pelbagai pertemuan baik tempatan mahupun antarabangsa. Dalam konteks ini, Malaysia memiliki peranan yang sangat penting melalui "World Conference on International Islamic Calendar" pada 29 Rabiul Awal hingga 2 Rabiul Akhir 1412 H (8 hingga 10 Oktober 1991) bertempat di Universiti Sains Malaysia (USM) Penang. Pertemuan ini menghasilkan program dan langkah menuju penyatuan Kalendar Islam Antarabangsa yang terkenal dengan istilah "Deklarasi Penang 1991".

11 Pegangan Negara Brunei Darussalam dalam penentuan awal Syawal ialah dengan hanya menggunakan kaedah ru'yah. Ru'yah akan dilakukan pada 29 Ramadan untuk menentukan awal bulan Syawal. Jika hilal gagal dilihat, negara Brunei Darussalam akan menggenapkan kepada 30 hari konsisten dengan hadis dan pendapat Mazhab Syafi'i. Sementara itu hisab pada pandangan Brunei, hanya sebagai panduan untuk melakukan rukyat sahaja dan tidak digunakan untuk menentukan awal bulan, walaupun posisi hilal telah memenuhi kriteria imkanur rukyat MABIMS. Selengkapnya lihat Shahir Akram Hassan dan Mohd Shukri Hanapi, Prosedur Operasi Piawai (SOP) dalam Penentuan Awal Syawal di Negara Brunai Darussalam (Pulau Pinang: Pusat Kajian Pengurusan Pembangunan Islam (ISDEV) Universiti Sains Malaysia, 2015).

12 Hal ini disebabkan awal Zulkaedah 1440 ditetapkan pada 4 Julai 2019 (Khamis) sebagaimana tercantum pada Kalendar Islam Brunei Darussalam Tahun 1440 yang diputuskan oleh Mahkamah Syariah. Kenyataan ini juga dibenarkan oleh Hj. Mahadi. Lihat Hj. Mahadi (Ahli Falak Brunei Darussalam), dalam temu bual beliau bersama penulis pada 13 Julai $2019 \mathrm{M} / 10$ Zulkaidah $1440 \mathrm{H}$. 
Deklarasi terdiri atas 18 resolusi. Salah satu perkara penting dalam deklarasi tersebut adalah:

“ Himbauan kepada pemerintah muslim, organisasi regional dan internasional untuk menggunakan imkanur rukyat (visibilitas hilal) yang dikembangkan berdasarkan program Kalender Islam Internasional sebagai basis untuk kalender kegiatan mereka. Kriteria ini harus dikaji ulang setelah lima tahun dan sebaiknya dilakukan penelitian secara berkesinambungan." 13

Pernyataan di atas menjelaskan bahawa teori visibilitas hilal sangat dinamik dan terbuka untuk dikaji secara terusmenerus. Sayangnya dalam kajian Kalendar Islam Antarabangsa berikutnya, hasil Deklarasi Penang 1991 ini kurang memperoleh perhatian, bahkan terlupakan. Memasuki tahun 2000-an, semangat mewujudkan Kalendar Islam Global muncul kembali melalui pertemuan di Amman Jordan pada 29 hingga 31 Oktober 2001 "The Second Islamic Astronomical Conference" diselenggarakan oleh The Arab Union of Astronomy and Space Sciences (AUASS) bekerjasama dengan Jordanian Astronomy Society (JAS) dan The Jordanian Ministry Affairs. ${ }^{14}$ Begitu juga Ijtima' al-Khubarai al-Tsani yang diadakan di Maghribi pada 15 hingga 16 Syawal 1429H (15 hingga 16 Oktober 2008). Dalam pertemuan ini, syaratsyarat Kalendar Islam Global dan usulan dibentuk bagi mengkaji empat kalendar, iaitu Kalendar al-Husain Diallo, Kalendar Libya,

13 Selengkapnya lihat Mohammad Ilyas dan Zhari Ismail. Towards A Unified World Islamic Calendar the Penang Declaration on The International Islamic Calendar, (Penang: University of Science Malaysia, 1413 H/1992 M), 15-17. Lihat juga Mohammad Ilyas. Kalendar Islam Antarabangsa, cet. I, (Kuala Lumpur: Dewan Bahasa dan Pustaka, 1996), 69-97.

14 Lihat Susiknan Azhari, Penyatuan Kalender Islam dari Solidaritas Individual-Sektarian Menuju Solidaritas Kebangsaan-Keumatan, cet. 1 (Yogyakarta: Museum Astronomi Islam, 2020), 157. 
Kalendar Ummul Qura, dan Kalendar Hijriah Terpadu (at-Taqwim al-Muwahhad). ${ }^{15}$

Dukungan penggunaan Kalendar Hijriah Global juga muncul pada pertemuan "The Thirty-Seventh Session of The Council of Foreign Ministers (Session of Shared Vision of A More Secure and Prosperous Islamic World" bertempat di Dushanbe, Tajikistan pada 4-6 Jumadil Akhir 1431 H (18-20 Mei 2010) dan pada "The Second Emirates Astronomical Conference " pada 16 hingga 18 Jamadil Akhir 1431 (30 Mei hingga 1 Jun 2010). Dalam pertemuan ini, Jamaluddin Abdur Razik, Khalid Syawkat, dan Muhibullah Durani sangat menyokong pewujudan Kalendar Islam Global. Jamaluddin merupakan salah seorang tokoh yang sangat aktif mempromosikan Kalendar Islam Terpadu dengan prinsip satu hari satu tanggal untuk seluruh dunia melalui karya pentingnya yang berjudul "At-Taqwim al-Qamary al-Islamy alMuwahhad. ${ }^{16}$

Jamaluddin menganggap susunan atau organisasi waktu merupakan persoalan yang sangat penting bagi kehidupan manusia, dan Islam menambah erti penting tersebut dengan mengkaitkannya kepada banyak ritual ibadah, seperti salat, puasa, zakat, dan wukuf di Arafah kaitannya dengan ibadah haji. ${ }^{17}$ Ia merupakan tokoh awal penggagas Kalendar Islam Global Unifikatif dengan prinsip satu hari satu tanggal di Seluruh dunia. Sebelumnya memang sudah ada tokoh yang menggagas tentang Kalendar Islam yang bersifat antarabangsa tetapi konsep yang dikembangkan berbeza dengan konsep Jamaluddin. Namun perlu dicatat salah satu prinsip Kalendar Islam Global Unifikatif Jamaluddin sangat dipengaruhi konsep ijtimak dengan panduan Kalendar Ummul Qura pada era Fadl Muhammad Ahmad (1393/1973-1419/1998). ${ }^{18}$

15 Selengkapnya lihat Syamsul Anwar. Diskusi \& Korespondensi Kalender Hijriah Global, cet. 1, (Yogyakarta: Suara Muhammadiyah, 2014), 191-205.

16 Baca Jamal Eddine Abderrezik. At-Taqwim al-Qamary al-Islami alMuwahhad, cet. 1, (Rabat: Marsam, 2004), 18-27.

17 Ibid, 1.

18 Susiknan Azhari, Penyatuan Kalender Islam Dari Solidaritas Individual-Sektarian Menuju Solidaritas Kebangsaan-Keumatan, 64. 
Terlepas pengaruh dari Kalendar Ummul Qura, Kalendar Islam Unifikatif memberi harapan baru bagi usaha penyatuan Kalendar Islam Global. Terbukti pada Persidangan Penyatuan Kalendar Islam di Istanbul Turki 2016M/1437H, sistem kalendar yang digagas Jamaluddin Abdur Razik dikaji oleh Tim Ahli yang dikoordinasikan oleh Jalaluddin Khanji dan akhirnya terpilih sebagai kalendar yang dijadikan rujukan untuk diimplementasikan dengan modifikasi sebagai berikut:

a) Seluruh kawasan dunia dipandang sebagai satu kesatuan di mana bulan baru dimulai pada hari yang sama di seluruh kawasan dunia tersebut.

b) Bulan baru dimulai apabila di bahagian manapun di muka bumi sebelum jam 24 (jam 00:00) Waktu Universal (WU)/GMT telah memenuhi kriteria berikut: jarak sudut antara matahari dan bulan (elongasi) pada waktu matahari terbenam mencapai 8 darjah atau lebih, dan ketinggian hilal di atas ufuk ketika matahari terbenam mencapai 5 darjah atau lebih.

c) Apabila kriteria pada nombor 2 di atas terjadi setelah jam 00:00 WU/GMT maka bulan baru tetap dimulai dengan ketetapan (a) apabila imkanur rukyat hilal menurut kriteria Istanbul 1978 sebagaimana dikemukakan di atas telah terjadi di suatu tempat mana pun di dunia dan ijtimak di New Zealand terjadi sebelum fajar, dan (c) imkanur rukyat tersebut (sebagaimana pada huruf a) terjadi di daratan benua Amerika. ${ }^{19}$

Prinsip-prinsip Kalendar Islam Global hasil Persidangan Turki 2016 memiliki asas epistemologi yang memungkinkan pewujudan "Satu Hari Satu Tanggal untuk Seluruh Dunia". Hanya umat Islam belum memberikan apresiasi positif sepenuhnya terhadap hasil Turki 2016. Kecenderungan penolakan lebih dipengaruhi dari aspek fiqh. Mereka menganggap bahawa keputusan Turki 2016 mengabaikan "fiqh" berkaitan konsep matlak yang selama ini menjadi panduan. Apabila hasil Turki 2016 diimplementasikan, maka banyak wilayah yang belum memenuhi kriteria "dipaksa" mengikuti wilayah yang sudah masuk.

19 Syamsul Anwar, Studi Islam Kontemporer Bagian Dua, cet. 1 (Yogyakarta: UAD Press, 2020), 240. 
Bagi menjawab persoalan di atas, kajian dijalankan melalui "Seminar Internasional Fikih Falak Peluang dan Tantangan Implementasi Kalendar Hijriah Tunggal" bertempat di Hotel Aryaduta Jakarta pada 29 hingga 30 November 2017 yang dihadiri oleh peserta daripada lima buah negara, iaitu Indonesia, Jordan, Malaysia, Singapura, dan Brunei Darussalam. Pertemuan ini membentuk Rekomendasi Jakarta 2017. Salah satu perkara penting dalam rekomendasi ini menyatakan bahawa Rekomendasi Jakarta 2017 pada prinsipnya merupakan penambahbaikan dan/ atau penyempurnaan, serta dapat menjadi pelengkap kriteria yang telah ada sebelumnya, iaitu kriteria Istanbul Turki 2016 dengan melakukan penambahbaikan menjadi kriteria elongasi minimum 6.4 darjah dan tinggi minimum 3 darjah dengan markaz kawasan Barat Asia Tenggara. ${ }^{20}$

Rekomendasi Jakarta 2017M/1438H tersebut mengisyaratkan perubahan yang dilakukan hanyalah berkaitan kriteria, sedangkan prinsip-prinsip Kalendar Islam Global tetap merujuk kepada kriteria Istanbul Turki 2016. Penulis membandingkan keduanya dalam tempoh waktu 10 tahun (120 bulan) sejak tahun 1442 H/2020 M-1452 H/2030 M. Hasilnya selama 10 tahun, terdapat 66 kali (55\%) kriteria Istanbul Turki 2016 lebih awal dalam memulai awal bulan kamariah dibandingkan hasil Rekomendasi Jakarta 2017, dan 54 kali (45\%) keduanya memulai awal bulan kamariah secara bersama. Data ini menunjukkan kriteria Istanbul Turki 2016 lebih memenuhi syarat sebagai Kalendar Islam Global dibandingkan kriteria Rekomendasi Jakarta 2017.

Salah satu kes kriteria Istanbul Turki 2016 lebih awal dibandingkan kriteria Rekomendasi Jakarta 2017 adalah ketika menentukan awal Safar 1442 H. Menurut kriteria Rekomendasi Jakarta 2017 pada 17 September 2020 (Khamis) bertepatan 29 Muharam 1442, kedudukan hilal di Kawasan Barat Asia Tenggara belum dipenuhi sehingga umur bulan Muharam 1442 $\mathrm{H}$ digenapkan kepada 30 hari (istikmal) sehingga awal Safar $1442 \mathrm{H}$ adalah pada 19 September 2020 (Sabtu). Sebaliknya jika menggunakan konsep kalendar Uhadi hasil Turki 2016, pada 17

\footnotetext{
20 Susiknan Azhari, Penyatuan Kalender Islam Dari Solidaritas Individual-Sektarian Menuju Solidaritas Kebangsaan-Keumatan, 236.
} 
September 2020 (Khamis) sudah terdapat wilayah yang memenuhi kriteria yang ditetapkan sehingga awal Safar $1442 \mathrm{H}$ adalah pada 18 September 2020 (Jumaat). Hal ini menunjukkan penggenapan bulan Muharam 1442 H kepada 30 hari berdasarkan Rekomendasi Jakarta 2017 adalah dianggap sebagai penundaan bagi ketibaan bulan baharu disebabkan terdapat pemenuhan kriteria pada tempat yang lain.

\section{KESIMPULAN}

Berdasarkan huraian di atas, konsep dasar yang dikembangkan Kalendar Uhadi Turki 2016 perlu disokong dan disosialisasikan secara berterusan agar difahami oleh masyarakat secara meluas. Sedangkan kriteria yang akan dipilih masih memerlukan kajian secara komprehensif. Hal ini kerana kriteria Turki 2016 memiliki kecenderungan menarik wilayah yang belum memenuhi kriteria kerana dianggap satu kesatuan. Begitu juga kriteria Rekomendasi Jakarta 2017 akan menarik wilayah yang sudah memenuhi disebabkan kawasan Barat Asia Tenggara yang belum memenuhinya. Kehadiran Kalendar Islam Global adalah sebuah keniscayaan (satu perkara yang tidak dapat dielakkan). Salah satu cabaran dalam mengimplementasikan Kalendar Hijriah Global di Era Revolusi Industri 4.0 adalah habit of mind dalam kalangan umat Islam yang masih meyakini kalendar hijriah bersifat lokal. Untuk itu, tahawwul al-fikr diperlukan dari tempatan menuju global melalui penyegaran kembali dalam memahami hadis-hadis ru'yah dan matla'.

\section{RUJUKAN}

Ahmad Yusof Farid Abdullah. Kaedah Penetapan Awal Ramadhan \& Syawal dan Pembentukan Taqwim Hijri di Malaysia. Pulau Pinang: Jabatan Mufti Pulau Pinang, t.t.

Azhari Muhammad. "Pembentukan Takwim Islam Malaysia Tahun 2000.” Kertas kerja, Muzakarah Pegawai-pegawai Falak Seluruh Malaysia di Hotel Seri Malaysia Kuala Terengganu, 8-12 September 1999. 
Haji Md Khair Haji Md Taib. Takwim Hijriah Khairiah. Bangi: Penerbit Universiti Kebangsaan Malaysia, 1987.

Jamal Eddine Abderrezik. At-Taqwim al-Qamary al-Islami alMuwahhad. Rabat: Marsam, 2004.

Klaus Schwab. Revolusi Industri Keempat. Jakarta: Gramedia, 2020.

Mohammad Ilyas dan Zhari Ismail. Towards A Unified World Islamic Calendar the Penang Declaration on The International Islamic Calendar. Penang: University of Science Malaysia, 1992.

Mohammad Ilyas. Kalendar Islam Antarabangsa. Kuala Lumpur: Dewan Bahasa dan Pustaka, 1996.

Mohd Saiful Anwar Mohd Nawawi et al. "History of the Criteria for Lunar Crescent Visibility in Malaysia." Jurnal alTamaddun 10, no. 2 (2015), 62-75.

Mohd Saiful Anwar Mohd Nawawi, "Penilaian Semula Kriteria Kenampakan Anak Bulan di Malaysia, Indonesia dan Brunei," Tesis Doktor Falsafah, Jabatan Fiqh dan Usul, Akademi Pengajian Islam, Universiti Malaya, Kuala Lumpur, 2013.

Muhammad Shawkah 'Awdah. "al-Ma'āyir al-Falākiyyah li bad'i al-Ashhūr al-Hijriyyah fī al- 'Alam al-Islāmī wa Waqi' alUmmah fī al-Waqt al-Rahin." Kertas kerja, The Preparation Meeting for International Crescent Observation Conference, Istanbul Turki, 18-19 Februari 2013.

Shahir Akram Hassan dan Mohd Shukri Hanapi. Prosedur Operasi Piawai (SOP) dalam Penentuan Awal Syawal di Negara Brunai Darussalam. Pulau Pinang: Pusat Kajian Pengurusan Pembangunan Islam (ISDEV) Universiti Sains Malaysia, 2015.

Susiknan Azhari. "Gagasan Menyatukan Umat Islam Indonesia." Jurnal Ahkam 15, no. 2 (2015), 249-258.

Susiknan Azhari. Catatan \& Koleksi Astronomi Islam dan Seni. Yogyakarta: Museum Astronomi Islam, 2015.

Susiknan Azhari. Penyatuan Kalender Islam Dari Solidaritas Individual-Sektarian Menuju Solidaritas KebangsaanKeumatan. Yogyakarta: Museum Astronomi Islam 2020. 
Syamsul Anwar. Studi Islam Kontemporer Bagian Dua. Yogyakarta: UAD Press, 2020.

Syamsul Anwar. Diskusi \& Korespondensi Kalender Hijriah Global. Yogyakarta: Suara Muhammadiyah, 2014.

Thomas Djamaluddin. Astronomi Memberi Solusi Penyatuan Ummat. Jakarta: LAPAN, 2011.

www.icoproject.org. diakses pada 20 Julai 2019.

\section{Temu bual}

Hj. Mahadi (Ahli Falak Brunei Darussalam), dalam temu bual beliau bersama penulis pada 13 Julai 2019/10 Zulkaidah $1440 \mathrm{H}$. 


\section{LAMPIRAN}

Lampiran 1: Kalendar Turki 2016 Lebih Awal

\begin{tabular}{|c|c|c|c|c|c|}
\hline No. & Tahun & Jumlah & No & Tahun & Jumlah \\
\hline 1. & 1442 & 8 & 6 & 1447 & 7 \\
\hline 2. & 1443 & 8 & 7 & 1448 & 8 \\
\hline 3. & 1444 & 5 & 8 & 1449 & 5 \\
\hline 4. & 1445 & 7 & 9 & 1450 & 6 \\
\hline 5. & 1446 & 5 & 10 & 1451 & 7 \\
\hline \multicolumn{5}{|c|}{ Jumlah } \\
\hline
\end{tabular}

Lampiran 2: Kalendar Turki 2016 dan Rekomendasi Jakarta 2017 Bersamaan

\begin{tabular}{|c|c|c|c|c|c|}
\hline No. & Tahun & Jumlah & No & Tahun & Jumlah \\
\hline 1. & 1442 & 4 & 6 & 1447 & 5 \\
\hline 2. & 1443 & 4 & 7 & 1448 & 4 \\
\hline 3. & 1444 & 7 & 8 & 1449 & 7 \\
\hline 4. & 1445 & 5 & 9 & 1450 & 6 \\
\hline 5. & 1446 & 7 & 10 & 1451 & 5 \\
\hline \multicolumn{7}{|c|}{ Jumlah } \\
\hline
\end{tabular}

